\title{
Isolation and characterization of diethyl phthalate degrading bacteria from crude oil contaminated soil
}

\begin{tabular}{l}
\hline Paper received: 13.07.2018 \\
\hline Authors Info \\
P.K. Çevik', A.B. Eroğlu', \\
G. Yildizli', D. Coşan', \\
Ç. Kantar' and G. Coral' ${ }^{2 *}$ \\
'Department of Biology, Faculty \\
of Science and Letters, Mersin \\
University, Mersin, 33343, Turkey \\
${ }^{2}$ Department of Biotechnology, \\
Faculty of Science and \\
Letters, Mersin University, \\
Mersin, 33343, Turkey \\
${ }^{3}$ Department of Environmental \\
Engineering, Faculty of Engineering, \\
Çanakkale Onsekiz Mart University, \\
Çanakkale, 17100, Turkey
\end{tabular}

\section{Edited by \\ Dr. Ghazwan Faisal Fadhil}

Reviewed by

Dr. R.B. Raizada

Dr. K. Divakar

\section{Abstract}

Aim : The aim of this study was to isolate, identify and characterize diethyl phthalate degrading bacterial strains isolated from a crude oil contaminated soil from a landfill dump site of a petroleum refinery in Mersin, Turkey.

Methodology : The bacteria was isolated from a crude oil contaminated soil and characterized by 16 S rRNA analysis. Bacterial genomic DNA was identified by $16 \mathrm{~S}$ rRNA analyses. Biodegredation experiments were conducted for 5 days and plasmid curing experiment was performed. Catechol test was carried out to determine phthalate degradation pathways.

Results : The isolated bacteria from soil were identified as Pseudomonas putida based on 16S rRNA sequences. The size of the plasmid was estimated to be about $15.9 \mathrm{~kb}$. Results of biodegradation experiments indicated that the diethyl phthalate concentrations were reduced by $85.5 \%$ after 5 days of incubation at $\mathrm{pH} 7.0$ and $30^{\circ} \mathrm{C}$. The ability of $P$. putida degrading diethyl phthalate was found to be plasmidmediated through curing experiments.

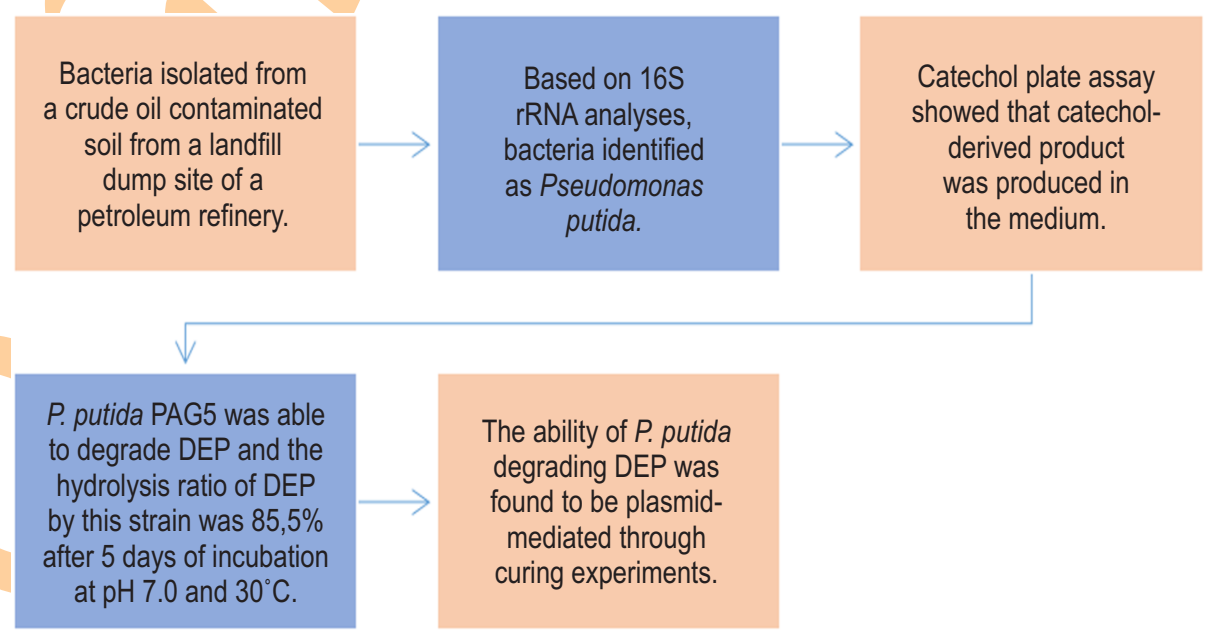

Interpretation : The study suggested that plasmid of Pseudomonas putida PAG5 could be involved in effective degradation of diethyl phthalate.

Key words: Biodegradation, Diethyl phthalate, Phthalate esters, Plasmid, Pseudomonas putida

How to cite : Çevik, P.K., A.B. Eroğlu, G. Yildizli, D. Coşan, Ç. Kantar and G. Coral: Isolation and characterization of diethyl phthalate degrading bacteria from crude oil contaminated soil. J. Environ. Biol., 40, 275-282 (2019). 


\section{Introduction}

Phthalate esters have been widely used to increase flexibility, strength as plasticizers in plastic industry in polyvinyl chloride, also cosmetic industry, medical sector and stationery products (Babu and $\mathrm{Wu}, 2010$ ). Because of their unique properties like chemical stability, flexibility, softening, ease of fabrication and low cost, phthalate esters are used with different chemical formulations. With an annual production of 14.4 million tons, dimethylphthalate and terephthalate are among the top 50 most produced chemicals worldwide (Li and Gu, 2006). Due to their widespread use and unstable chemical bond, phthalate esters have become ubiquitous environmental pollutant. Phthalate esters have been found in natural waters, drinking waters, soils and atmosphere, because they cannot bond to the host polymers (Marttinen et al., 2003; Fang et al., 2007; Sun et al., 2013). Phthalate esters are released in soils, aquatic habitats and have been observed to accumulate in living biota (Lu et al., 2009). Long-term adverse effects in most living organisms contaminated with diethyl esters of phthalic acid have been reported (Kapanen et al., 2007; Cheng, 2012; Ghorpade et al., 2002; Xiao et al., 2018). Several studies have reported correlation of phthalate esters with DNA mutation, hepatic disorders and carcinoma (Dillingham and Autian, 1973; Gesler 1973; Koch et al., 2003; Zeng et al., 2004; Den Hond and Schoeters, 2006; Singh and Li, 2011). Diethyl ester of phthalic acid is a clear, colorless, practically odorless liquid. It has a boiling point of $298^{\circ} \mathrm{C}$, specific gravity of $1.12\left(20^{\circ} \mathrm{C}\right)$, vapor pressure of $<0.001$ torr $\left(20^{\circ} \mathrm{C}\right)$ and molecular weight $222.24 \mathrm{~g} \mathrm{~mol}^{-1}$ Api (2001). Most phthalate esters, especially diethyl esters of phthalic acid are toxic and disturb endocrine system in living organisms (Chang et al., 2007).

Unfortunately, phthalate esters cannot be degraded effectively by natural processes such as hydrolization and photodecomposition. The basic chemical structure of phthalates is benzene dicarboxylic acid with two side chains, which can be alkyl, benzyl, phenyl, cycloalkyl or alkoxy groups. Studies have demonstrated that phthalates with shorter ester chains like dimethyl phthalate (DMP), diethyl phthalate (DEP), dibutyl phthalate (DBP), diphenyl phthalate (DPP), dipropyl phthalate (DPrP), and butyl-benzyl phthalate (BBP) can be readily biodegraded and mineralized. On the other hand, phthalates with longer ester chains, such as dicyclohexylphthalate, dihexyl phthalate (DHP), dioctyl phthalate (DOP), and di-2-ethylhexyl phthalate (DEHP) are less susceptible to biodegradation (Chang and Zylstra, 1998). However, biodegradation is a successful mechanism of phthalate removal in aquatic and soil habitats ( $\mathrm{Lu}$ et al. 2009). Since many bacterial strains can breakdown phthalate esters under aerobic and anaerobic conditions, most phthalate-degrading bacteria are mainly from four divisions in Bacteria, i.e., Proteobacteria, Actinobacteria (or high $\mathrm{G}+\mathrm{C}$ ), Firmicutes (or low $\mathrm{G}+\mathrm{C}$ ), and Bacteroids / Chlorobi. Among them, the commonly found genera are Sphingomonas, Comamonas and Pseudomonas (Kapanen et al., 2007). Vamsee-Krishna et al. (2006) showed that bacterial strains utilized three phthalate isomers as sole carbon sources. Kim et al. (2008) studied the degradation of DPP and they reported the biodegradation of DPP by Sphingomonas chungbukensis. Degradation of phthalate esters proceed by the action of esterases to form phthalate isomers, which are converted into dihydroxylated intermediates by specific and inducible phthalate isomer dioxygenases. Metabolic pathways of phthalate isomers converge at 3,4dihydroxybenzoic acid, which then undergoes either ortho-or meta-ring cleavage and is subsequently metabolized to the central carbon pathway intermediates. Genes involved in degradation are arranged in operons present either on plasmid or chromosome or both, and induced by specific phthalate isomer (Vamsee-Krishna and Phale, 2008). Pseudomonas can also metabolize aromatic compounds such as toluene, benzene, ethylbenzene, phenol and also phthalate isomers as sole carbon and energy sources (Reardon et al., 2000). In light of the above, the aim of this study was to isolate and characterize DEP degrading bacterial strains from crude oil contaminated soil samples. The present investigation also focused on the genetic determination of degradation capabilities of strains in this isolate.

\section{Materials and Methods}

Soil samples: Soil samples were collected from a crude oilcontaminated soil, near a petroleum refinery, Mersin, Turkey. The soil samples (approximately, $500 \mathrm{~g}$ ) were transferred to Molecular Biology and Biotechnology Laboratory with sterile conditions for further analysis.

Isolation of DEP-degrading bacteria: The culture medium was a modified minimal salt medium (MSM). The final $\mathrm{pH}$ of the medium was adjusted to $\mathrm{pH} 7.0$ (Chang, 2004). Yeast extract was added to the medium at $0.5 \%(\mathrm{w} / \mathrm{v})$. The final product was named as MSMY. The medium agar was prepared with $14 \mathrm{~g} \mathrm{l}^{-1}$ agar. The overnight bacterial inoculum was prepared in Nutrient Broth medium. The DEP concentration was adjusted to $100 \mathrm{mg} \mathrm{I}^{-1}$ using a surfactant.

Isolation of DEP degrading bacteria was carried out by the method of Kuce et al. (2015). One gram of soil sample was added to $5 \mathrm{ml}$ of sterile distilled water, and the suspension was centrifuged at $2000 \mathrm{rpm}$ for $10 \mathrm{~min}$. Then, $1 \mathrm{ml}$ of supernatant was

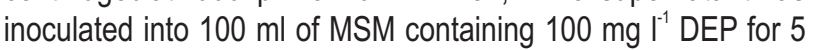
days at $150 \mathrm{rpm}$ and $30^{\circ} \mathrm{C}$. One $\mathrm{ml}$ of culture was then transferred to another $100 \mathrm{ml}$ fresh MSM with $200 \mathrm{mgl}^{-1}$ DEP. After incubation under similar conditions, $1 \mathrm{ml}$ of this last culture was transferred to $100 \mathrm{ml}$ fresh MSM with $300 \mathrm{mg} \mathrm{l}^{-1}$ DEP. The final enrichment culture was spread over MSM Agar (MSMA) plates that contained $100 \mathrm{mg} \mathrm{l}^{-1} \mathrm{DEP}$ as the main carbon source. After incubation for 5 days, bacterial colonies were cultivated in Nutrient Agar (NA) plates for overnight at $30^{\circ} \mathrm{C}$. Bacterial colonies were then transferred into fresh MSMA with DEP. Bacterial strains were picked up and replated three times to ensure pure colony selection. The best growing colony was selected and stored in MSM with $20 \%$ glycerol at $-80^{\circ} \mathrm{C}$ until further use.

Preparation of DEP stock with surfactant: As diethyl phthalate has low water solubility, a surfactant was added to MSM in order 
to ensure its dispersion in the medium. DEP was prepared with Triton X-100 (2 $\left.\mathrm{mg} \mathrm{l}^{-1}\right)$ in MSM medium. The mixture was strongly blended with vortex up to provide white color discoloration.

16S rRNA analysis: Genomic DNA of bacteria was isolated with Nano Biz Genomic DNA Isolation Kit. The PCR was performed using a reaction volume of $50 \mu$ including $1 X$ Taq buffer, $1.5 \mathrm{mM}$ $\mathrm{MgCl}_{2}, 0.2 \mathrm{mM}$ dNTP mix, $0.3 \mathrm{pmol}$ of each primer, $1.5 \mathrm{U}$ Taq polymerase. 16S rRNA gene was amplified by universal primers 27F (5'-AGAGTTTGATCCTGGCTCAG-3') and 1492R (5'GGTTACCTTGTTACGACTT-3'). PCR was conducted following cycle parameters; denaturation for $1 \mathrm{~min}$ at $95^{\circ} \mathrm{C}$ followed by 30 cycles of $45 \mathrm{sec}$ at $94^{\circ} \mathrm{C}, 45 \mathrm{sec}$ at $55^{\circ} \mathrm{C}$ and 45 sec at $72^{\circ} \mathrm{C}$. Bigdye Cycle Sequencing kit v.3.1 was used for sequence analysis. Sequencing regions were carried out using an ABI 3100 Genetic Analyzer. Sequence data were classified with reference genomes using Molecular Evolutionary Genetics Analysis (MEGA) and its software MEGA5 (Tamura et al., 2011). The phylogenetic tree was designated by using the minimum evolution tree method (Hall, 2013).

Biodegradation of DEP: One $\mathrm{ml}$ of $24 \mathrm{hr}$ grown bacterial culture was inoculated in MSMY with $100 \mathrm{ppm}$ DEP. The culture was incubated in a shaker at $150 \mathrm{rpm}$ at $30^{\circ} \mathrm{C}(\mathrm{pH} 7.0)$ for 5 days. The biomass growth and concentrations of DEP were monitored on the 5 th day of experiment. Optical density $\left(\mathrm{OD}_{600}\right)$ of the samples were measured with spectrophotometer (Analytik Jena-Specord 210 Plus) everyday to assess the bacterial cell growth. All the experiments were performed in triplicate and a graph was made by taking the average of the obtained values.

Analytical procedure: One $\mathrm{ml}$ samples were taken from the flask daily. The samples were then centrifuged (Sigma D-37520) at $10.000 \mathrm{~g}$ for $10 \mathrm{~min}$. The supernatant was filtered by $0.2 \mu \mathrm{m}$ sterile filter. After filtration, $500 \mu$ of supernatant was mixed with $500 \mu$ l of $n$-hexane $(99 \%)$. The mixture was stirred for $3 \mathrm{hrs}$. At the end of this process, phase separation was completed and supernatant was filtrated through YM-3 membrane filter to remove the salts, used in the medium. Finally, the extract in nhexane was analyzed with GC-MS (GC Agilent 7890A, MS Agilent 5975C) using a gas column (HP5MS, 2 m long, 3 mm diameter) packed with silicon. The temperature at the injection port was $280^{\circ} \mathrm{C}$ and the oven temperature was programmed from $50^{\circ} \mathrm{C}$ ( $2 \mathrm{~min}$ ) to $280^{\circ} \mathrm{C}(5 \mathrm{~min})$ at $10^{\circ} \mathrm{C} \mathrm{min}{ }^{-1}$ interval. $\mathrm{A} 4 \mu \mathrm{l}$ of each sample was injected into the column (Babu, 2010; Kim et al., 2008; Quan et al., 2005).

Plasmid curing: The plasmid curing procedure was performed by the method of Trevors (1986). In short, the culture was incubated in Nutrient Broth containing $500 \mathrm{~g} \mathrm{I}^{-1}$ ethidium bromide for $24 \mathrm{hr}$ at $30^{\circ} \mathrm{C}$. The overnight culture was plated on nutrient agar and MSM agar with $100 \mathrm{mgl}^{-1} \mathrm{DEP}$.

DNA isolation and agarose gel electrophoresis: Plasmid DNA was purified by using Gene JET Plasmid Miniprep Kit (Thermo Fisher). The reactions were performed as outlined in the manufacturer's instructions. DNA fragments were electrophoresed through agarose gel $(0.7 \%)$ at $60 \mathrm{~V}$ for $3 \mathrm{hr}$ in TBE Buffer $(45 \mathrm{Mm}$ Tris-Borate, 1mM EDTA, pH: 8.0). Gels were stained with $0.5 \mu \mathrm{g} \mathrm{m}^{-1}$ ethidium bromide and were observed on a UV-transilluminator. $1 \mathrm{~kb}$ DNA Ladder was used as molecular size marker (Gene Ruler, MAN0013004, and Thermo Scientific). Molecular size of plasmid DNAs were determined with DNA size software.

Catechol plate assay: Catechol test was carried out to determine phthalate degradation pathways and origin of the gene responsible for degradation of phthalates. Bacterial strain was cultivated in MSM overnight. Fresh culture was mixed equal volume of $0.1 \mathrm{M}$ catechol in an E-plate and incubated for $30 \mathrm{~min}$ at $30^{\circ} \mathrm{C}$ under static conditions, then color change of liquid medium was observed (Haigler, 1992; Mikesell et al., 1993).

Modeling of DEP degradation kinetics: Assuming that the environmental conditions (e.g., pH, temperature) are constant, a simplified pseudo-first order rate law can be derived to model diethyl phthalate degradation kinetics at pH 7.0 and $30^{\circ} \mathrm{C}$ (Küce et al., 2015):

$$
\frac{\mathrm{d}[\mathrm{C}]}{\mathrm{dt}}=\mathrm{k}[\mathrm{C}]
$$

The integrated form of this rate law is

$$
\frac{\ln [\mathrm{C}]}{\left[\mathrm{C}_{0}\right]}=-k t
$$

where, $\mathrm{C}$ is the model predicted concentration of diethyl phthalate concentration $\left(\mathrm{mg} \mathrm{l}^{-1}\right), \mathrm{C}_{0}$ is the initial diethyl phthalate concentration, $k$ is the first order kinetics rate constant $\left(d^{-1}\right)$. The software Scientist (Micromath) was used to fit related questions to the DEP removal data as well as to test the statistical validity of model simulations. Note that the first-order rate model accurately simulated the kinetic data with a regression coefficient $R^{2}>0.991$. The value of $k$ as estimated from the slope of the model simulation was $0.5265 d^{-1}$, which corresponded to a half-life $\left(t_{1 / 2}\right)$ of $1.32 d$.

\section{Results and Discussion}

The crude oil polluted soils were collected from a petroleum refinery landfill site to prepare an enrichment culture MSM containing DEP as sole carbon source. Two different surfactants (Tween-80 and Triton X-100) were selected to obtain the best water solubility of DEP. The results of this investigation show that the maximum water solubility of DEP was observed with Triton X-100. Tween-80 did not provide enough water solubility of DEP in MSM and insoluble part of DEP accumulated to form droplets in the aqueous phase of the medium. The culture was continuously enriched at 5-day interval. Following the culture enrichment procedure, the best-growing bacterial strains were selected for identification. A phylogenetic tree was constructed based on the 16S rRNA sequence of the strains isolated (Fig. 1) (Tamura et al., 2011; Hall, 2013). Sequence alignment results showed very high similarities (>99\%) to Pseudomonas putida NBRC 14164 (Ohji et al., 2014). Thus, the isolated strain was 


\begin{tabular}{|c|c|c|c|c|c|}
\hline Pseudomonas monteilii strain Al-Khri4 \\
Pseudomonas entomophila strain Q1-9-2 \\
Pseudomonas mosselii strain LJ26
\end{tabular}

Fig. 1: Phylogenetic tree with bootstrap values $(n=500)$ based on $16 S$ rRNA sequences, showing the position of strain PAG5 $(\bullet)$ relative to related strains.

named as Pseudomonas putida PAG5 in this study. Pseudomonas genus is known to be one of the most common bacterial species in soil environment and capable of degrading various organic pollutants, such as phthalates, naphthalene, fluorene and phenanthrene (Vamsee-Krishna et al., 2006; Yang et al., 1994; Nalli et al., 2002). The results showed that $P$. putida PAG5 was able to grow in MSM medium with DEP as a sole carbon source and energy. While the concentration of DEP decreased from 100 to $10 \mathrm{mg} \mathrm{I}^{-1}$ in the solution, the optical density increased from 0.16 to 0.3 , indicating that DEP was used as a carbon source and led to an increase in microbial growth. The hydrolysis ratio of DEP by this strain was $85.5 \%$ after 5 days of incubation at $\mathrm{pH} 7.0$ and $30^{\circ} \mathrm{C}$. (Fig. 2). Fig. 3 shows experimental data and model simulations for DEP degradation. it was noteworthy that DEP degradation kinetics followed a first-order rate model with a regression coefficient $R^{2}>0.991$ (Küce et al., 2015).

The value of first order reaction rate constant $(k)$, as estimated from the slope of the model simulation, was $0.5265 \mathrm{~d}^{-1}$. This value is comparable to the values reported for DEP in the literature (Lu et al., 2009). First-order kinetics have been used frequently to describe DEP biodegradation progress at low substrate concentrations. Zeng et al. (2004) investigated the biodegradation kinetics of DEP, DMP, di-n-butyl phthalate (DnBP), diisobutyl phthalate (DIBP), di-n-octyl phthalate (DnOp) and (DEHP) by Pseudomonas fluoresences Fs1. According to the results of this study, more than $99 \%$ of DEP was degraded in less than $96 \mathrm{hr}$. Due to persistence in the nature, microbes have evolved and adapted new pathways to degrade phthalate esters. Bacterial degradation is efficient as these compounds are either biotransformed or mineralized completely. Degradation of phthalate isomers can be both by aerobic and anaerobic routes. Many bacterial strains have been reported to degrade phthalate esters as sole carbon sources. Among the reported phthalate degraders, very few strains like Pseudomonas testosteroni EN 5a, Pseudomonas aeruginosa strain PP4 and Comamonas testosteroni strain E6 (Vamsee-Krishna et al., 2006; Keyser et al., 1972; Yan and Pan, 2004; Sasoh et al., 2006).

Phthalate esters are metabolized to phthalate by esterases. Phthalate is dihydroxylated to yield phthalate dihydrodiol, which is subsequently metabolized to 3,4dihydroxybenzoate (3,4-DHB). 3,4-DHB is ring cleaved either by protocatechuate 3,4-dioxygenase (ortho pathway) or protocatechuate 4,5-dioxygenase (meta pathway) leading to tricarboxylic acid cycle. Genes involved in the metabolism of phthalate isomers are present either on plasmids, chromosome, insertion elements or both on plasmid and chromosome (Vamsee-Krishna and Phale, 2008). The catechol test carried out as chromogenic substrate in this experiment showed a yellow/green colorization in the medium (Haigler, 1992; Mikesell et al., 1993). This result indicated that catecholderived product was produced in the medium (Fig.4A). In 


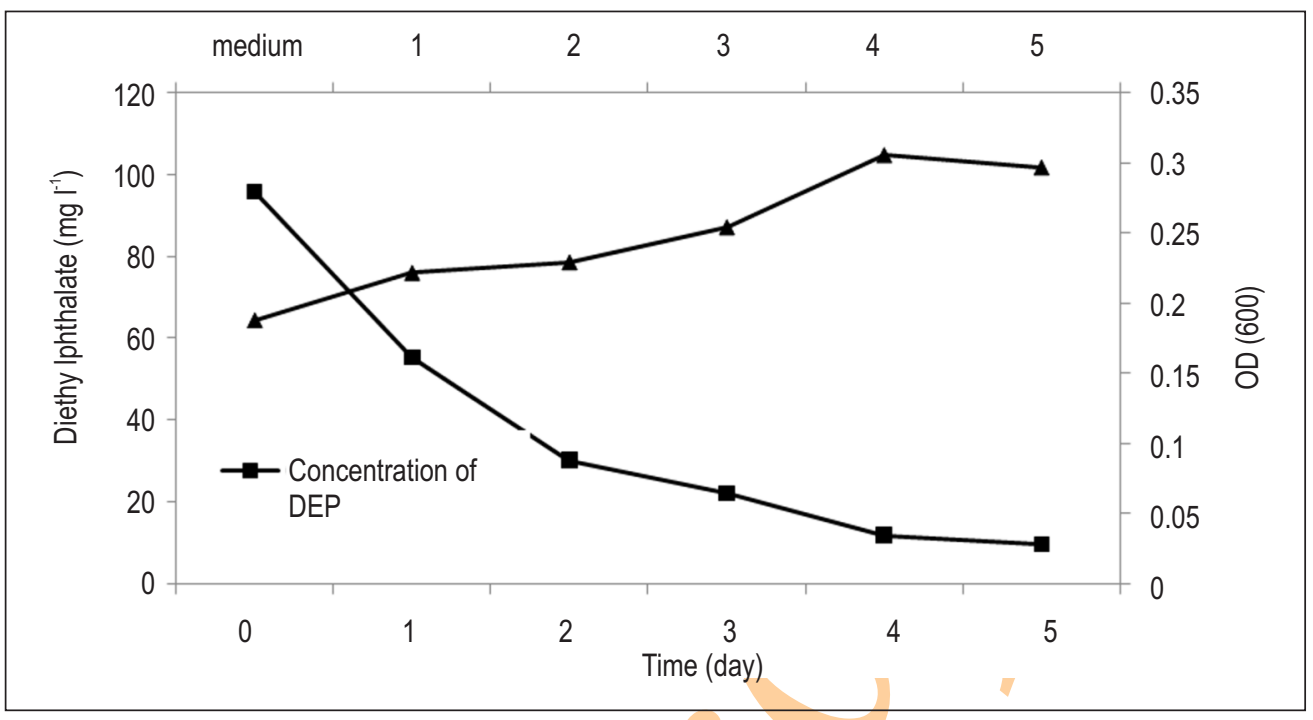

Fig. 2: Biodegradation of DEP by P. putida PAG5 strain.

addition, plasmid curing experiment showed that bacterial growth was observed in NA plate, but no colony was observed in MSMA plate after curing experiment with ethidium bromide. Yellow/green color formation in the medium was not observed in the cured bacterial culture, catechol-derived product was not detected in the medium of plasmid cured bacteria, suggesting that the ability of $P$. putida PAG5 for degrading DEP is plasmidencoded (Fig. 4. A, B). Plasmid DNA of $P$. putida PAG5 was successfully isolated with commercial DNA isolation kits. The reactions were performed according to the manufacturer's instructions. The DNA fragments were electrophoresed through agarose gel $(0.7 \%)$ at $60 \mathrm{~V}$ for $3 \mathrm{hr}$. The results of agarose gel electrophoresis showed that the size of plasmid DNA was about $15.9 \mathrm{~kb}$. In contrast, no band was observed after curing experiment (Fig.5). Electrophoretic separation profiles of plasmidic DNA isolated from non-cured cultures showed that $P$. putida PAG5 contained an approximately $15.9 \mathrm{~kb}$-sized plasmid. In Arthrobacter keyseri, it was previously shown that

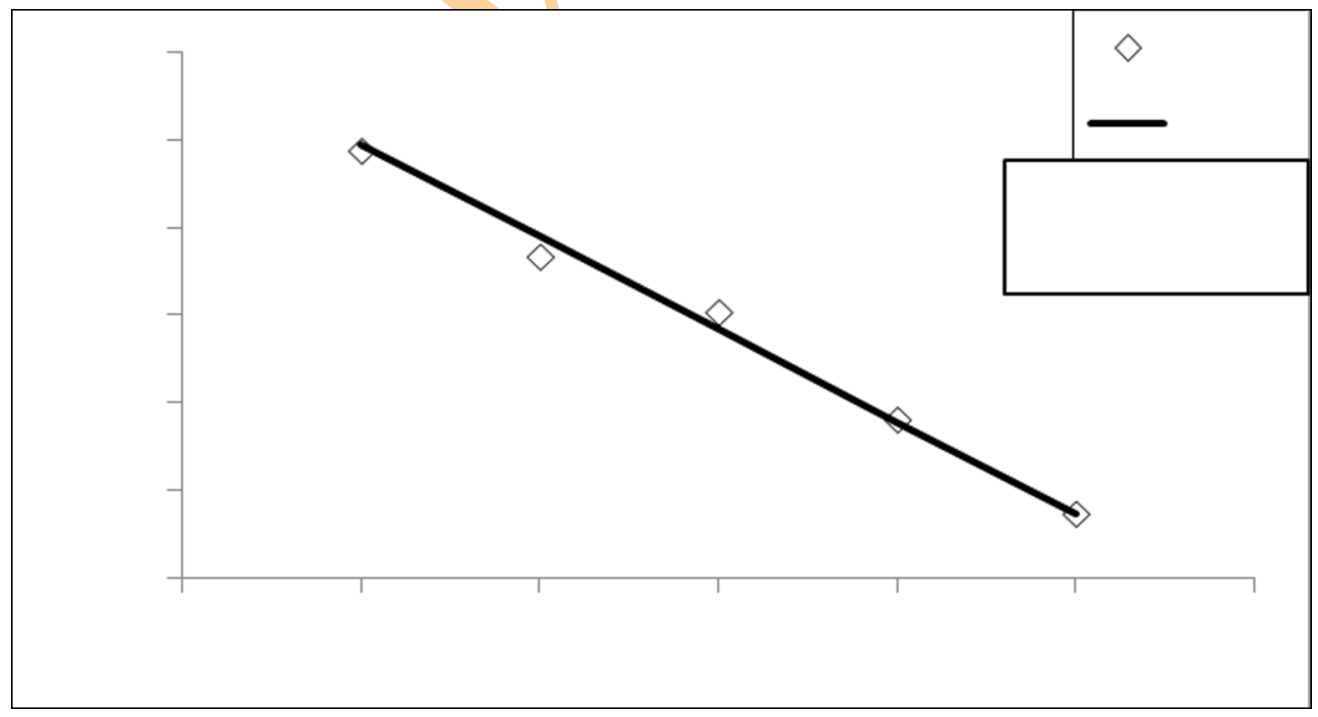

Fig. 3: DEP removal kinetics at $\mathrm{pH} 7.0$ and temperature $30^{\circ} \mathrm{C}$. The solid line represents the first order rate expression. 


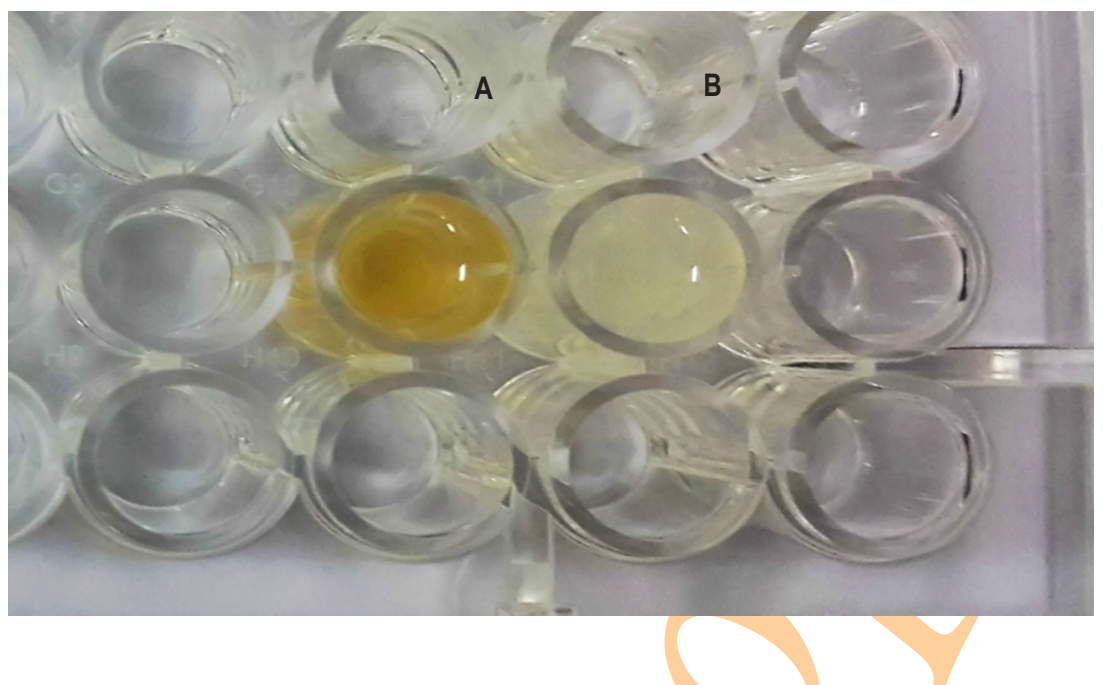

Fig. 4: Catechol plate assay indicating that catechol derived intermediates were produced by P. putida PAG5. Yellow/green color (A) disappeared in medium of the cured bacteria (B).

$26.3 \mathrm{~kb}$ of plasmid (pRE1-130 kb) harbors genes encoding proteins for degradation of phthalate (Eaton, 2001). A 200kilobase pair (kbp) DNA plasmid, named PHT, was detected in a strain of Pseudomonas putida, NMH102-2, that utilized phthalate effectively through 4,5-dihydroxyphthalate pathway (Nomura et al., 1990). A large plasmid of approximately $140 \mathrm{~kb}$ in size was found to be involved in the degradation of phthalates in Pseudomonas fluorescens. The catabolic plasmid pSKL was observed to be transferable to different hosts (Karpagam and Lalithakumari, 1999). It was reported that Pseudomonas sp. strain PPD also metabolizes phenanthrene via phthalate. The cell-free extracts of phthalate grown cells showed enzyme activities of protocatechuate 3,4-dioxygenase while phenanthrene grown cells exhibited protocatechuate 4,5-dioxygenase activity,

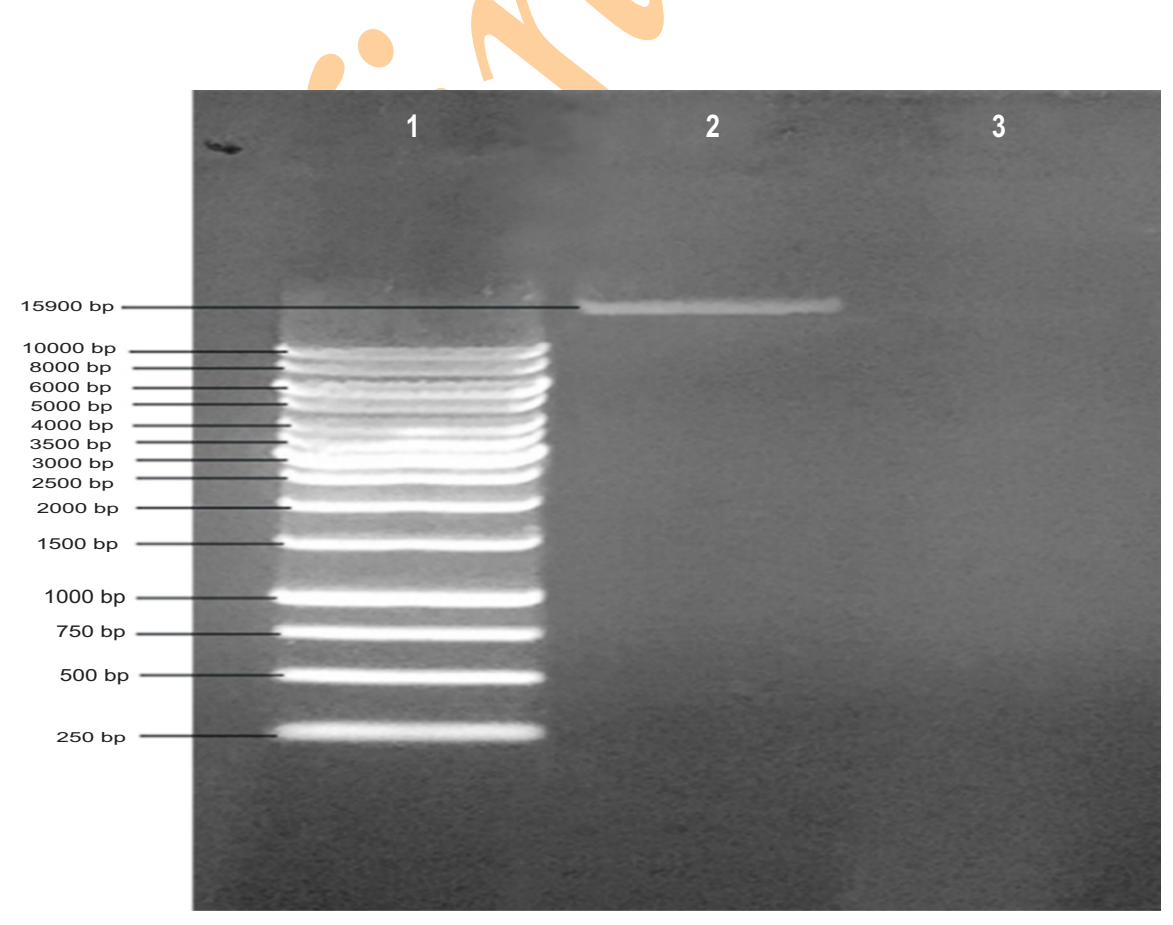

Fig. 5: Separation profile of plasmids from P. putida PAG5 by agarose gel electrophoresis. Lane1 DNA size marker (1 kb DNA ladder), Lane 2 plasmid DNA, Lane 3 No plasmidic DNA band was observed after curing process. 
suggesting that Pseudomonas sp. strain PPD has diverse pathways for phthalate metabolism (Deveryshetty et al., 2007). In an earlier study, it has been reported that a small NAH like plasmid (26 kb) in Pseudomonas sp. strain, isolated from same crude oil polluted refinery area (Coral and Karagoz, 2005).

This study suggests that plasmid of $P$. putida PAG5 could be involved in DEP biodegradation, and might also play a significant role in biodegradation of other xenobiotics such as PAHs. However, further molecular studies should be carried out to clear diverse pathways for phthalate metabolism in this bacterial species.

\section{Acknowledgment}

This work was supported by Mersin University Scientific Research Fund (No. BAP FBE BB (DC) 2012-8 YL)

\section{References}

Api, A. M.: Toxicological profile of diethyl phthalate: A vehicle for fragrance and cosmetic ingredients. Food and Chemical Toxicol., 39, 97-108 (2001).

Babu, B. and J.T. Wu: Biodegradation of phthalate esters by cyanobacteria. J. Phycology, 46, 1106-1113 (2010).

Chang, B. V., C. M. Yang, C. H. Cheng and S. Y. Yuan: Biodegradation of phthalate esters by two bacteria strains. Chemosphere, 55, 533538 (2004).

Chang, B.V., T.H. Wang and S.Y. Yuan: Biodegradation of four phthalate esters in sludge. Chemosphere, 69, 1116-1123 (2007).

Chang, H.K. and G.J. Zylstra: Novel organization of the genes for phthalate degradation from Burkholderia cepacia DBO1. J. Bacteriol., 180, 6529-6537(1998).

Coral, G. and S. Karagoz: Isolation and characterization of phenanthrene-degrading bacteria from a petroleum refinery soil. Annals of Microbiology, 55, 255-259 (1998).

Cheng, T.S.: The toxic effects of diethyl phthalate on the activity of glutamine synthetase in greater duckweed (Spirodela polyrhiza L.). Aqua. Toxicol., 124, 171-178 (2012).

Den Hond, E. and G. Schoeters: Endocrine disrupters and human puberty. Int. J. Androl., 29, 264-271 (2006).

Deveryshetty, J., V. Suvekbala, G. Varadamshetty and P.S. Phale: Metabolism of 2-,3-and 4-hydroxybenzoates by soil isolates Alcaligenes sp. strain PPH and Pseudomonas sp. strain PPD. FEMS Microbiol. Lett., 268, 59-66 (2007).

Dillingham, E.O. and J. Autian: Teratogenicity, mutagenicity and cellular toxicity of phthalate esters. Environ. Hlth. Perspec., 3, 81-89 (1973).

Eaton, R.W.: Plasmid-encoded phthalate catabolic pathway in Arthrobacter keyseri 12B. J. Bacteriology, 183, 3689-3703 (2001).

Fang, H. H., D. Liang and T. Zhang: Aerobic degradation of diethyl phthalate by Sphingomonas sp. Bioreso. Technol., 98, 717-720 (2007).

Gesler, R. M.: Toxicology of di-2-ethylhexyl phthalate and other phthalic acid ester plasticizers. Environ. Hith. Perspec., 3, 73-79 (1973).

Ghorpade, N., V. Mehta, M. Khare, P. Sinkar, S. Krishnan and C. V. Rao: Toxicity study of diethyl phthalate on freshwater fish Cirrhina mrigala. Ecotoxico. Environm. Safety, 53, 255-258 (2002).

Haigler, B.E., C.A. Pettigrew and J.C. Spain: Biodegradation of mixtures of substituted benzenes by Pseudomonas sp. strain Js150. Appli. Environ. Microbiol., 58, 2237-2244 (1992).
Hall, B.G.: Building phylogenetic trees from molecular data with MEGA. Mole. Biol. Evolut, 30, 1229-1235 (2013).

Jonsson, S., J. Ejlertsson and B.H Svensson: Behaviour of mono-and diesters of o-phthalic acid in leachates released during digestion of municipal solid waste under landfill conditions. Advan. Environ. Res., 7, 429-440(2003).

Kapanen, A., J. R. Stephen, J.Brüggemann, A.Kiviranta, D.C. White and M. Itävaara: Diethyl phthalate in compost: Ecotoxicological effects and response of the microbial community. Chemosphere, 67, 2201-2209 (2007)

Kapanen, A., J.R. Stephen, J. Brüggemann, A. Kiviranta, D.C. White and M. Itavaara: Diethyl phthalate in compost: Ecotoxicological effects and response of the microbial community. Chemosphere, 67, 2201-2209 (2007).

Karpagam, S. and D. Lalithakumari: Plasmid-mediated degradation of oand p-phthalate by Pseudomonas fluorescens. World J. Microbiol. Biotechnol., 15, 565-569 (1999).

Keyser, P., B.G.Pujar, R.W. Eaton and D.W. Ribbons: Biodegradation of the phthalates and their esters by bacteria. Environ. Hith. Perspec., 18, 159-166 (1976).

Kim, D.S., H.J. Um, E.S. Lim, J. Min and Y.H. Kim: Degradation of diphenyl phthalate by Sphingomonas chungbukensis. Biotechnol., Lett., 30, 93-96 (2008).

Koch, H.M.,H. Drexler and J. Angerer: An estimation of the daily intake of di (2-ethylhexyl) phthalate (DEHP) and other phthalates in the general population. Int. J. Hygi. Environ. HIth., 206, 77-83 (2003).

Küce, P., G. Coral and Ç. Kantar: Biodegradation of 2, 4-dinitrotoluene (DNT) by Arthrobacter sp. K1 isolated from a crude oil contaminated soil. Annals Microbiol., 65, 467-476 (2015).

$\mathrm{Li}$, J. and J.D.Gu: Biodegradation of dimethyl terephthalate by Pasteurella multocida Sa follows an alternative biochemical pathway. Ecotoxicology, 15, 391-397 (2006).

Lu, Y., F. Tang, Y. Wang, J. Zhao, X. Zeng, Q. Luo and L. Wang: Biodegradation of dimethyl phthalate, diethyl phthalate and di-nbutyl phthalate by Rhodococcus sp. L4 isolated from activated sludge. J. Hazard. Materi., 168, 938-943 (2009).

Marttinen, S.K., R.H. Kettunen and J.A. Rintala: Occurrence and removal of organic pollutants in sewages and landfill leachates. Sci. Total Environ., 301, 1-12 (2003).

Mikesell, M.D., J.J. Kukor and R.H. Olsen. Metabolic diversity of aromatic hydrocarbon-degrading bacteria from a petroleum-contaminated aquifer. Biodegradation, 4, 249-259 (1993).

Nalli, S., D.G. Cooper and J.A. Nicell: Biodegradation of plasticizers by Rhodococcus rhodochrous. Biodegradation, 13, 343-352 (2002).

Nomura, Y., S. Harashima and Y. Oshima: PHT, a transmissible plasmid responsible for phthalate utilization in Pseudomonas putida. J. Fermen. Bioengin., 70, 295-300 (1990).

Ohji, S., A. Yamazoe, A. Hosoyama, K. Tsuchikane, T. Ezaki and N. Fujita: The complete genome sequence of Pseudomonas putida NBRC 14164T confirms high intraspecies variation. Genome Announce., 2 (2014). DOI: 10.1128/genomeA.00029-14.

Quan, C.S., Q. Liu, W.J. Tian, J. Kikuchi and S.D. Fan: Biodegradation of an endocrine-disrupting chemical, di-2-ethylhexyl phthalate, by Bacillus subtilis No. 66. Appl. Microbiol. Biotechnol., 66, 702-710 (2005).

Reardon, K. F., D.C. Mosteller and J.D. Bull Rogers: Biodegradation kinetics of benzene, toluene, and phenol as single and mixed substrates for Pseudomonas putida F 1. Biotechnol. Bioengin., 69, 385-400 (2000).

Sasoh, M., E.Masai, S. Ishibashi, H. Hara, N. Kamimura, K. Miyauchi and M. Fukuda: Characterization of the terephthalate degradation genes of Comamonas sp. strain E6. Appli. Environ. Microbiol., 72, 1825-1832 (2006).

Singh, S. and S. S. L. Li: Phthalates: Toxicogenomics and inferred human 
diseases. Genomics, 97, 148-157 (2011).

Sun, J., J. Huang, A. Zhang, W. Liu and W. Cheng: Occurrence of phthalate esters in sediments in Qiantang River, China and inference with urbanization and river flow regime. J. Hazard. Materi., 248, 142-149 (2013).

Tamura, K., D. Peterson, N.Peterson, G.Stecher, M.Nei and S. Kumar: MEGA5: Molecular evolutionary genetics analysis using maximum likelihood, evolutionary distance and maximum parsimony methods. Molec. Biol. Evol., 28, 2731-2739 (2011).

Trevors, J.T.: Plasmid curing in bacteria. FEMS Microbiol. Reviews, 1, 149-157 (1986).

Vamsee-Krishna, C. and P.S. Phale: Bacterial degradation of phthalate isomers and their esters. Indian J. Microbiol., 48, 19-34 (2008).

Vamsee-Krishna, C., Y. Mohan and P.S. Phale: Biodegradation of phthalate isomers by Pseudomonas aeruginosa PP4,
Pseudomonas sp. PPD and Acinetobacter Iwoffii ISP4. Appl. Microbiol. Biotechnol., 72, 1263-1269 (2006).

Yan, H., and G. Pan: Increase in biodegradation of dimethyl phthalate by Closterium lunula using inorganic carbon. Chemosphere, 55, 1281-1285 (2004).

Yang, Y., R.F. Chen and M.P. Shiaris: Metabolism of naphthalene, fluorene, and phenanthrene: Preliminary characterization of a cloned gene cluster from Pseudomonas putida NCIB 9816. J. Bacteriol., 176, 2158-2164 (1994).

Xiao, Q., D. Li, R. Guo, L. Zheng, X. An and Z. Zeng: In vivo and in vitro toxicities of diethyl phthalate to flounder fish Paralichthys olivaceus and its gill cell line (FG cells). J. Environ. Biol., 39, 73-81 (2018).

Zeng, F., K. Cui, X. Li, J. Fu and G. Sheng: Biodegradation kinetics of phthalate esters by Pseudomonas fluoresences FS1. Process Biochem., 39, 1125-1129 (2004). 